\title{
GENETIC STRUCTURE OF PERCH PERCA FLUVIATILIS (L.) POPULATIONS IN LATVIAN RIVERS THAT ARE FRAGMENTED (DAUGAVA) AND NON-FRAGMENTED (LIELUPE) BY HYDROELECTRIC DAMS
}

\author{
Natalja Škute\#, Jelena Oreha, Baiba Krivmane, and Arina Evarte \\ Institute of Life Science and Technology, Daugavpils University, 1A Parādes Str., Daugavpils, LATVIA \\ \# Corresponding author, natalja.skute@du.Iv
}

Communicated by Isaak Rashal

\begin{abstract}
Water ecosystems have an important role in maintenance of biological diversity and environmental quality in Latvia. Fish resources are one of the most valuable biological resources in Latvia. To evaluate the influence of economic activity (anthropogenic influence of cities, hydroelectric power stations) on freshwater ecosystems, the genetic structure of perch Perca fluviatilis (L.) populations in Daugava River and Lielupe River was studied. The genetic structure of the perch populations from Daugava River and Lielupe River was investigated using 9 DNA microsatellites (Pfla L4, Pfla L10, Pfla L2, Pfla L6, YP111, YP78, YP60, Svi L10, Svi L7), and by genetic diversity, the level of polymorphism, means of alleles per locus, observed and expected heterozygosity, and population structuring. It was shown that the perch population in the Daugava River in the territory of Riga was significantly different from the other populations and there was a lower level of heterozygosity in this population. In the Daugava River, genetic differentiation was significant for fish populations between Kegums Hydroelectric Power Plant (HPP) and Riga HPP reservoirs due to the fragmentation of population by HPP dams.
\end{abstract}

Keywords: fish population genetics, microsatellites, dams, fragmentation, anthropogenic factors.

\section{INTRODUCTION}

Fish resources are one of the most valuable biological resources in Latvia. Anthropogenic activity is diverse, but it can, in fact, be reduced to a few main effects, like the development of barriers in fish migration paths, transformation of habitats and a reduction in water quality. Concerns over habitat alterations and the subsequent effects on biodiversity have received much scientific attention during the last few decades. Particularly for aquatic diversity, conservationists are concerned that dams may fragment and diminish natural habitats in rivers (Dynesius and Nilsson, 1994; Khedkar et al., 2014) and create environmental disparities (Ward and Stanford, 1983) that can result in the loss of genetic diversity, reduced population sizes and inbreeding (Ellstrand and Elam, 1993; Lynch et al., 1995). Fish are in the highest positions of the food chain of aquatic ecosystems (Nfon et al., 2009). The anthropogenic influence of cities and navigable ports on rivers can affect the genetic structure of fish populations.

The Eurasian perch Perca fluviatilis (L.) is a freshwater, predatory fish that belongs to the most diverse fish order of Perciformes (Nelson, 2006). Perch is an anadromous species that is adapted to various habitats and is a quite common fish species in Europe. This fish is often chosen as a model species in many fish population investigations due to its abundance and wide distribution, extended genetic research, diploidy and no stocking effects (Behrmann-Godel and Gerlach, 2008; Nurminen et al., 2010; Butkauskas et al., 2012). Studies have been conducted on the consequences of overexploitation and subsequent population recovery of Eurasian perch (Perca fluviatilis L.) populations (Pukka et al., 2016), and the impacts of a nuclear power plant on the genetic structure of perch populations as an intensively exploited fish species (Ragauskas et al., 2014). It was shown that genetic differences are not related to geo- 
graphical distances, but probably depend on ecological characteristics (Fokina et al., 2015). Eurasian perch was used for investigations on the relative importance of genetic variation and plasticity on phenotypic variation (Svanbäck and Eklöv, 2006).

Microsatellites are short tandemly repeat sequences with high variability and rapid mutation rates, which are distributed throughout the genome and are co-dominant (Richard et al., 2008). Microsatellites are the most popular DNA markers in population research, due to their wide range of applications, high levels of polymorphism, relatively straightforward laboratory protocols and high repeatability (Abdul-Muneer, 2014). Microsatellites can reveal genetic structure over short geographical distances, including panmixia (Dannewitz et al., 2005) and isolation by distance patterns (O'Reilly et al., 2004), fragmentation of populations (Bahri-Sfar et al., 2000, Gouskov and Vorburger, 2016), and hybridisation (Gum et al., 2005). Microsatellite genotypes are particularly helpful to detect genetic structure, regardless of whether they are in evolutionary equilibrium. In addition, microsatellite markers have been widely used for non-model species, because it is possible to use primers that have been developed for related species or genera (Seeb et al., 2011; Škute and Oreha, 2016).
The aim of this study was to investigate the genetic structure of Eurasian perch Perca fluviatilis (L.) populations using microsatellite DNA markers in different areas of Latvian rivers. The populations analysed were taken from the two largest rivers in Latvia: in Daugava River - above and below the Kegums dam, as well as in the Riga city, and in the Lielupe River, which has no dam, in Jelgava city and the Lielupe estuary.

\section{MATERIAL AND METHODS}

Object of research and areas of material collection. The object of the research was populations of perch (Perca fluvatilis (L.) living in different parts of the Daugava and Lielupe Rivers. Tissue samples were collected in 2016 from a total of 80 perch individuals from five different Daugava and Lielupe River sites in Latvia: fish from the Daugava River collected in the Riga Hydroelectric Power Plant (HPP) (Tome), in Kegums HPP (Kegums), and near the estuary in Rīga city (Voleri), and fish from Lielupe River collected near the estuary (Grīva) and in Jelgava city (Fig. 1). Perch individuals were caught by recreational anglers using fishing rods. Sample tissues were stored at $-20{ }^{\circ} \mathrm{C}$.

Nuclear DNA extraction, DNA quantification, DNA qualification. DNA was extracted from perch muscle tis-

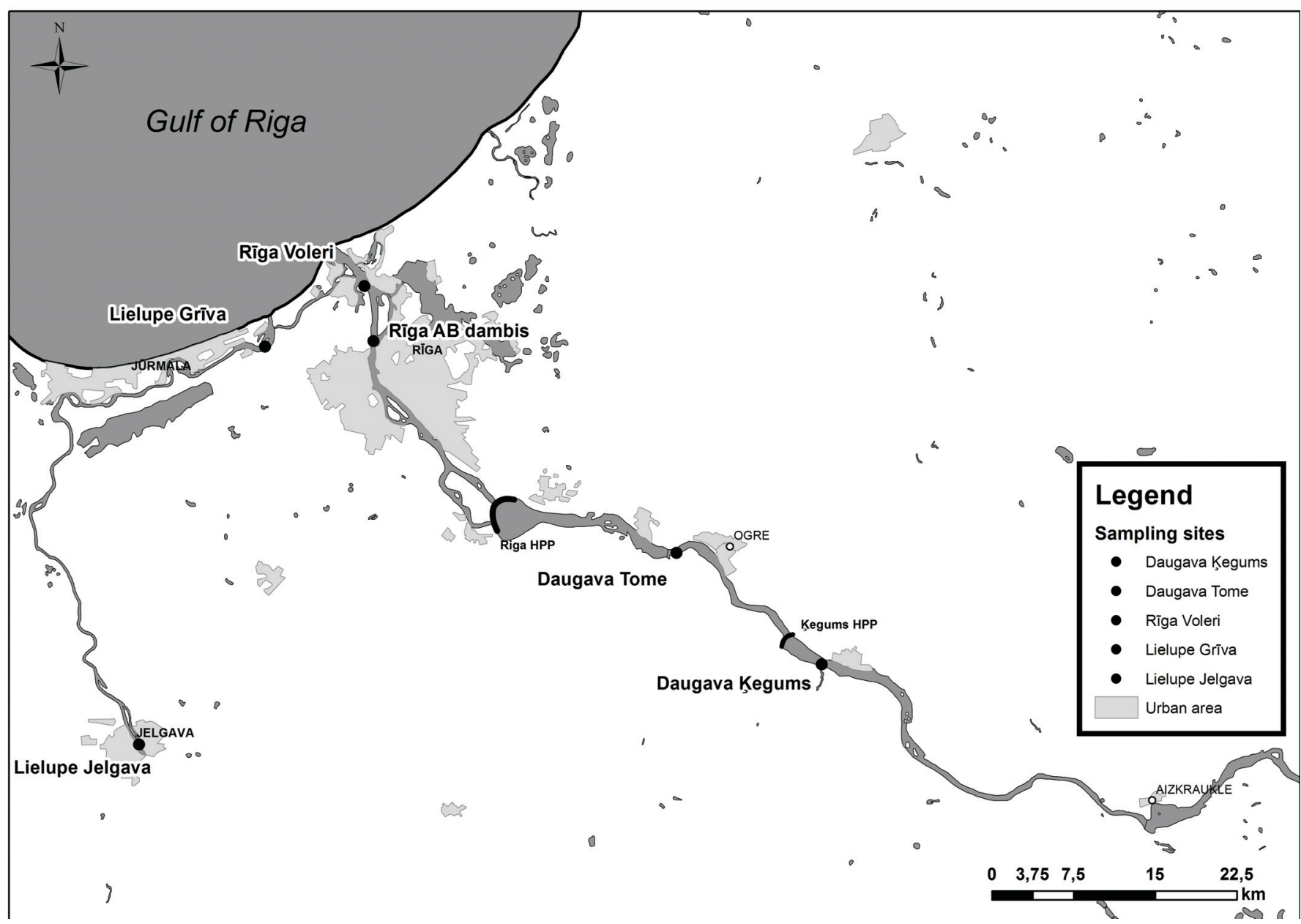

Fig. 1. The location of sampling sites of perch in Latvia. 
sues by the salt extraction method (Aljanabi and Martinez, 1997). DNA was quantified and qualified spectrophotometrically on a BioSpec-nano spectrophotometer (Shimadzu). DNA quality was estimated electrophoretically using $2 \%$ agarose gel (Sigma) in TBE buffer (0.045 M Tris-borate and $0.001 \mathrm{M}$ EDTA). The gels were stained with ethidium bromide at final concentration $0.5 \mu \mathrm{g} / \mathrm{ml}$. The size of the DNA fragments was estimated by comparing them to molecular markers using pUC19 DNA/MspI (HpaII) Marker (Thermo Fisher Scientific) and VisionWorks LS Software.

Microsatellite genotyping. The genetic structure of the perch populations was investigated using nine DNA microsatellite loci: Pfla L4, Pfla L10, Pfla L2, and Pfla L6 (Leclerc et al., 2000), YP111, YP78, and YP60 (Li et al., 2007). These loci were previously developed for yellow perch (Perca flavescens Mitchill) and Svi L10, Svi L7 (Wirth et al., 1999) and walleye (Stizostedion vitreum. Mitchill). One tetra-, two tri- and six dinucleotide microsatellite loci were amplified by polymerase chain reactions (PCR). PCR amplifications were performed in a total volume of $12 \mu \mathrm{l}$, containing 20-50 ng genomic DNA, 10× Taq Buffer with $\mathrm{KCl}$, $1.5 \mathrm{mM} \mathrm{MgCl} 2,2 \mathrm{mM}$ dNTP mix, $0.05 \mathrm{U} / \mu \mathrm{l}$ Taq DNA polymerase, and $3 \mathrm{pmol} / \mu \mathrm{l}$ of each primer. PCR was performed using an ABI 9700 thermocycler and the following thermal cycling programme: initial denaturation at $95{ }^{\circ} \mathrm{C}$ for $3 \mathrm{~min}$, then five cycles were run with $95{ }^{\circ} \mathrm{C}$ for $45 \mathrm{~s}, 48{ }^{\circ} \mathrm{C}$ for 40 $\mathrm{s}$, and $72{ }^{\circ} \mathrm{C}$ for $40 \mathrm{~s}$ and 22 cycles were run with $95{ }^{\circ} \mathrm{C}$ for $30 \mathrm{~s}, 52{ }^{\circ} \mathrm{C}$ for $40 \mathrm{~s}$, and $72{ }^{\circ} \mathrm{C}$ for $40 \mathrm{~s}$, followed by $2 \mathrm{~min}$ extension at $72{ }^{\circ} \mathrm{C}$ and cooling at $4{ }^{\circ} \mathrm{C}$. To assess the reproducibility of the amplification of DNA fragments, PCRs were repeated three times with each primer. In each amplification series both positive and negative controls were included. The investigated microsatellite markers have a good representation in perch populations. The general characterisation of these nine microsatellites primer pairs is shown in Table 1. The ABI PRISM $® 310$ genetic analyser was used to identify the size of the amplified microsatellites. The size of the amplified fragments was estimated using the size standard GeneScan ${ }^{\mathrm{TM}} 500 \mathrm{ROX}{ }^{\circledR}$ and the computer software GeneMapper® 3.7 (Applied Biosystems). All genotypes were manually inspected.

Statistical processing and analysis of the data. The obtained data were processed and analysed using computer softwares POPGENE 1.32 (Yeh et al., 1999) and GenAlEx 6.41 (Peakall and Smouse, 2006). Allele number per locus, frequency, private alleles in each population, observed and expected level of heterozygosity in polymorphic loci were measured, and their differences and significance with $\chi^{2}$ criteria were calculated using POPGENE 1.32 and GenAlEx 6.41 software. The software MICRO-CHECKER was used to identify potential null alleles (Van Oosterhout et al., 2004). The software MICRO-CHECKER aids in the identification of genotyping errors due to no amplified alleles (null alleles), short allele dominance (large allele dropout) and the scoring of stutter peaks, and can also detect other scoring errors. The genetic differentiation among the populations was estimated by principal component analysis (PCA) and pairwise $F_{S T}$ values (Nei, 1987). Bottleneck 1.2.02 (Cornuet et al., 1997) was used to determine bottleneck effects in the studied populations. In order to estimate and visualise the genetic structure and differentiation of the studied perch populations STRUCTURE 2.3 (Hubisz et al., 2009) and STRUCTURE HARVESTER (Earl, 2012) were used. The genetic relatedness of the populations was estimated with the help of Nei's (Nei et al., 1983) index of genetic distance $(D)$ using the computer software Populations 1.2.32 (Langella et al., 2005). The dendrogram was created using the Neighbor- Joining method with the computer software TREVIEW (Page, 1996).

Table 1. Analysed microsatellite loci

\begin{tabular}{|c|c|c|c|c|}
\hline Species & Locus & Repeat type & Primer sequence $\left(5^{`}-3^{\prime}\right)$ & Label dye \\
\hline Perca flavescens & Pfla L10 & $(\mathrm{TG})_{14}$ & $\begin{array}{l}\text { F: TCCACCCTTTGATAAGGGAC } \\
\text { R: ACAAATCTCCTGTCAAACGC }\end{array}$ & FAM \\
\hline Perca flavescens & Pfla L2 & $(\mathrm{CA})_{23}$ & $\begin{array}{l}\text { F: GTAAAGGAGAAAGCCTTAAC } \\
\text { R: TAGCATGACTGGCAAATG }\end{array}$ & FAM \\
\hline Perca flavescens & Pfla L6 & $(\mathrm{TG})_{18}$ & $\begin{array}{l}\text { F: GCATACATATAAGTAGAGCC } \\
\text { R: CAGGGTCTTCACTATACTGG }\end{array}$ & FAM \\
\hline Perca flavescens & Pfla L4 & $(\mathrm{TC})_{37}$ & $\begin{array}{l}\text { F: AAAGGGAAAAGGCTACGGTG } \\
\text { R: ATCAGCAGTGCTTATGTTTG }\end{array}$ & HEX \\
\hline Stizostedion vitreum & Svi L10 & $(\mathrm{CA})_{33}$ & $\begin{array}{l}\text { F: GGTAATGTATTTTCAGTTATTGC } \\
\text { R: GCTGTTCTCCAAGTAAAGCC }\end{array}$ & HEX \\
\hline Stizostedion vitreum & Svi L7 & $(\mathrm{TG})_{22}$ & $\begin{array}{l}\text { F: GATGTGCATACATTTACTCC } \\
\text { R: GCTTTAATCTGCTGAGAAC }\end{array}$ & FAM \\
\hline Perca flavescens & $Y P 78$ & $(\mathrm{GTA})_{13}$ & $\begin{array}{l}\text { F: GCAGCCCCTACAATGGTT } \\
\text { R:CAGTCGGGCGTCATCAGCCTTCTTCTGTTATTTTTCC }\end{array}$ & FAM \\
\hline Perca flavescens & $Y P 111$ & $\begin{array}{l}(\mathrm{CTA})_{16} \\
(\mathrm{ATA})_{18}\end{array}$ & $\begin{array}{l}\text { F:CAGTCGGGCGTCATCATGTGTATGGCTATTGTGCTC } \\
\text { R: TTTGTTCAGTGTTTTTTCGC }\end{array}$ & FAM \\
\hline Perca flavescens & YP60 & $(\mathrm{AGAA})_{10}$ & $\begin{array}{l}\text { F: ATGTGTTATTGCTTTGCGTA } \\
\text { R:AGTCGGGCGTCATCAGCTGTTCCTGTAATGTGTTG }\end{array}$ & HEX \\
\hline
\end{tabular}




\section{RESULTS}

We investigated the polymorphism of microsatellites river sites to examine the variability of microsatellites in five different particular Daugava and Lielupe sites of rivers, which are under the influence of different anthropogenic factors including fragmentation by the cascade of Daugava hydroelectric power stations. The analysed loci (Pfla L2, Pfla L4, Pfla L6, Pfla L10, YP60, YP78, YP111, Svi L7, and Svi L10) were polymorphic in the investigated perch populations and the level of polymorphism was very high. Genetic diversity across the studied perch samples found in each studied loci and each location are presented in Table 2. The greatest number of alleles (25) were found at locus $S v i$ L7 in the population from the Daugava River in Riga (Voleri), and the minimum number of alleles (1) at locus Pfla L6 was found in the population from Daugava River in the Ķegums HPP (Ķegums) and locus YP78 from Daugava River in Tome (data are not shown). Private alleles were found at the loci Pfla L2, Pfla L4, Pfla L6, Pfla L10, YP 60, YP78, YP111, Svi L7, and Svi L10 loci. Private alleles were found at loci Pfla L2, Pfla L6, and Svi L7 in each population. The maximum mean number of private alleles (4.00) was found in the Daugava River in Rịga city (Voleri_D) and the lowest number of mean values of private alleles was detected in the Daugava River in Riga HPP (Tome_D) and in K,egums HPP (K,egums_D) populations, with mean values of 0.67 and 0.89 , respectively (Table 2).

The level of observed and expected heterozygosity is shown in Figure 2. Observed heterozygosity $\left(H_{o b s}\right)$ was high in all studied populations, ranging from 0.57 to 0.75 . The minimum value of Hobs was 0.57 in Daugava River from Rìga HPP (Tome), and the maximum was 0.75 in Lielupe River from Jelgava. The average expected heterozygosity (Hexp) varied from 0.69 and 0.67 (in Daugava River in the Rīga HPP (Tome) and in the Kegums HPP (Kegums)) to 0.79 and 0.78 (in Lielupe River from Jelgava (Jelgava_L) and

Table 2. Genetic diversity across studied perch samples found in each studied loci and each location in Latvian rivers (Daugava River in Riga HPP (Tome_D), in Kegums HPP (Ķegums_D) and in Rīga (Voleri_D), Lielupe River in estuary (Grīva_L) and in Jelgava (Jelgava_L)

\begin{tabular}{|c|c|c|c|c|c|c|c|c|c|c|c|}
\hline Sample & & Pfla-L4 & Pfla-L10 & Pfla-L2 & Pfla-L6 & $S v i-L 7$ & $Y P 111$ & YP60 & Svil10 & YP78 & Total \\
\hline \multirow{6}{*}{$\begin{array}{l}\theta_{1} \\
\frac{\overrightarrow{0}}{0} \\
\frac{1}{>}\end{array}$} & $\mathrm{N}$ & 24 & 25 & 29 & 27 & 19 & 30 & 31 & 32 & 31 & 32 \\
\hline & $\mathrm{Na}$ & 11 & 16 & 19 & 9 & 25 & 9 & 20 & 4 & 4 & $13(2.46)$ \\
\hline & $\mathrm{Ne}$ & 5.333 & 7.022 & 12.188 & 4.166 & 19.514 & 4.337 & 14.561 & 2.330 & 1.957 & $7.93(2.03)$ \\
\hline & No & 1 & 4 & 4 & 4 & 18 & 1 & 4 & 0 & 0 & $4(1.85)$ \\
\hline & Ho & 0.792 & 0.800 & 0.793 & 0.000 & 0.947 & 0.633 & 0.903 & 0.563 & 0.387 & $0.65(0.10)$ \\
\hline & $\mathrm{He}$ & 0.813 & 0.858 & 0.918 & 0.760 & 0.949 & 0.769 & 0.931 & 0.571 & 0.489 & $0.78(0.5)$ \\
\hline \multirow{6}{*}{ 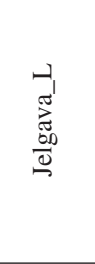 } & $\mathrm{N}$ & 11 & 11 & 11 & 9 & 11 & 11 & 11 & 11 & 11 & 11 \\
\hline & $\mathrm{Na}$ & 8 & 8 & 11 & 4 & 10 & 12 & 10 & 3 & 6 & $8(1.04)$ \\
\hline & $\mathrm{Ne}$ & 5.042 & 6.050 & 7.563 & 2.613 & 7.806 & 8.963 & 8.345 & 2.283 & 4.566 & $5.91(0.82)$ \\
\hline & No & 0 & 3 & 1 & 0 & 1 & 10 & 1 & 0 & 2 & $2(1.05)$ \\
\hline & Ho & 0.818 & 0.818 & 0.636 & 0.000 & 0.727 & 1.000 & 1.000 & 0.727 & 1.000 & $0.75(0.10)$ \\
\hline & $\mathrm{He}$ & 0.802 & 0.835 & 0.868 & 0.617 & 0.872 & 0.888 & 0.880 & 0.562 & 0.781 & $0.79(0.04)$ \\
\hline \multirow{6}{*}{ 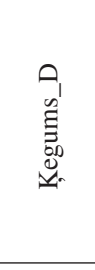 } & $\mathrm{N}$ & 7 & 7 & 7 & 1 & 3 & 7 & 7 & 2 & 3 & 7 \\
\hline & $\mathrm{Na}$ & 6 & 3 & 10 & 1 & 5 & 5 & 9 & 4 & 4 & $5.22(0.94)$ \\
\hline & $\mathrm{Ne}$ & 4.455 & 2.390 & 8.167 & 1.000 & 4.500 & 3.630 & 7.538 & 4.000 & 3.000 & $4.30(0.77)$ \\
\hline & No & 0 & 0 & 2 & 1 & 1 & 1 & 1 & 1 & 1 & $0.89(0.20)$ \\
\hline & Ho & 0.714 & 0.714 & 0.714 & 0.000 & 0.667 & 0.571 & 1.000 & 1.000 & 1.000 & $0.71(0.10)$ \\
\hline & $\mathrm{He}$ & 0.776 & 0.582 & 0.878 & 0.000 & 0.778 & 0.724 & 0.867 & 0.750 & 0.667 & $0.67(0.9)$ \\
\hline \multirow{6}{*}{ 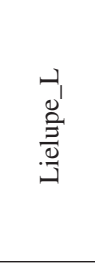 } & $\mathrm{N}$ & 23 & 23 & 23 & 16 & 22 & 23 & 23 & 23 & 18 & 23 \\
\hline & $\mathrm{Na}$ & 11 & 14 & 19 & 7 & 14 & 10 & 15 & 4 & 5 & $11(1.67)$ \\
\hline & $\mathrm{Ne}$ & 6.654 & 6.961 & 9.200 & 2.207 & 7.389 & 5.658 & 10.907 & 2.587 & 2.582 & $6.02(1.02)$ \\
\hline & No & 1 & 6 & 3 & 1 & 3 & 3 & 1 & 0 & 2 & $2.22(0.60)$ \\
\hline & Ho & 0.826 & 0.957 & 0.652 & 0.125 & 0.864 & 0.870 & 1.000 & 0.609 & 0.556 & $0.72(0.09)$ \\
\hline & $\mathrm{He}$ & 0.850 & 0.856 & 0.891 & 0.547 & 0.865 & 0.823 & 0.908 & 0.613 & 0.613 & $0.77(0.05)$ \\
\hline \multirow{6}{*}{$\begin{array}{l}\oplus^{\prime} \\
\stackrel{ٌ}{0} \\
\stackrel{0}{-}\end{array}$} & $\mathrm{N}$ & 7 & 7 & 7 & 4 & 5 & 7 & 7 & 6 & 3 & 7 \\
\hline & $\mathrm{Na}$ & 6 & 9 & 10 & 2 & 5 & 3 & 8 & 3 & 1 & $5.22(1.07)$ \\
\hline & $\mathrm{Ne}$ & 5.158 & 6.533 & 7.000 & 1.600 & 2.500 & 2.579 & 5.765 & 2.323 & 1.000 & $3.83(0.76)$ \\
\hline & No & 0 & 0 & 2 & 2 & 2 & 0 & 0 & 0 & 0 & $0.67(0.33)$ \\
\hline & Ho & 0.857 & 0.857 & 0.857 & 0.000 & 0.600 & 0.571 & 0.857 & 0.500 & 0.000 & $0.57(0.12)$ \\
\hline & $\mathrm{He}$ & 0.806 & 0.847 & 0.857 & 0.375 & 0.600 & 0.612 & 0.827 & 0.569 & 0.000 & $0.61(0.9)$ \\
\hline
\end{tabular}

$\mathrm{Na}$, the average number of alleles in a locus; Ne, the average effective number of alleles in a locus; No, the average number of private alleles; Ho, observed heterozygosity; He, expected heterozygosity, standard error values in parentheses 


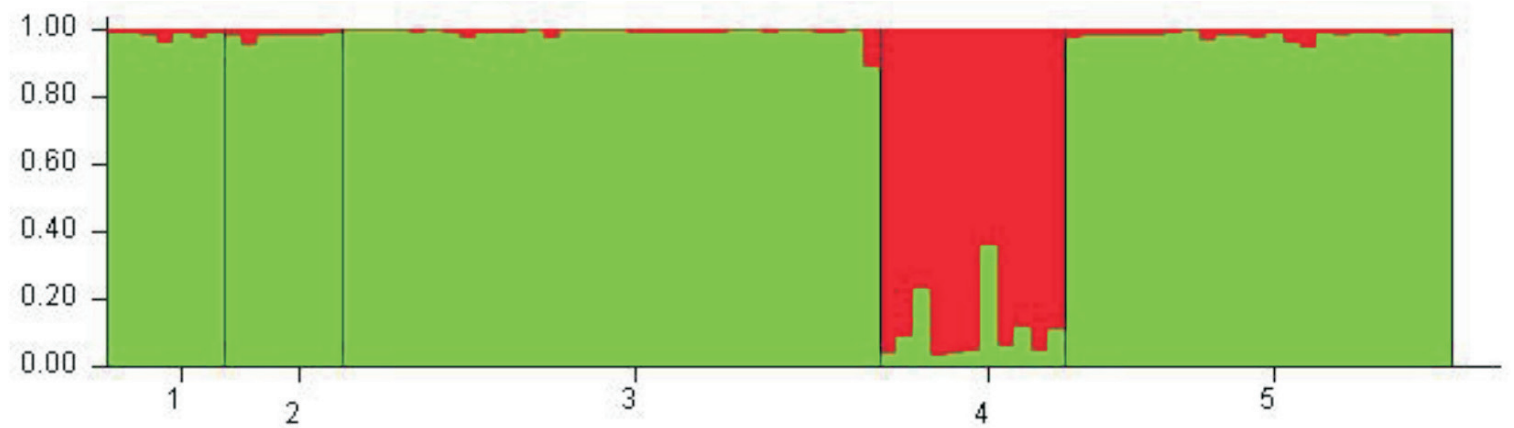

Fig. 2. Bayesian clustering of individuals using STRUCTURE (Hubisz et al., 2009) assuming two genetic clusters $(\mathrm{K}=2 ; \Delta \mathrm{K}=4.62 ; \ln \mathrm{P}(\mathrm{K}) \pm \mathrm{SD}=$ $-3021.04 \pm 10.04)$. In the STRUCTURE analysis black lines separate individuals from different sampling sites and each individual is represented by a thin vertical line, which is partitioned into K-coloured segments representing an individual's estimated membership fractions in K clusters (1 - Kegums_D, 2 -Tome_D, 3 - Voleri_D, 4 - Jelgava_L, 5 - Grīva_L).

Table 3. Significance $\left(\chi^{2}\right.$-test) of differences between the levels of observed and expected heterozygosity in five studied perch samples collected in two Latvian rivers

\begin{tabular}{|c|c|c|c|c|c|c|c|c|c|}
\hline $\begin{array}{c}\text { Populations/ } \\
\text { microsatellite loci }\end{array}$ & Pfla L4 & Pfla L10 & Pfla L2 & Pfla L6 & Svi L7 & Svi L10 & YP78 & $Y P 111$ & YP60 \\
\hline Ķegums_D & ns & $\mathrm{ns}$ & $\mathrm{ns}$ & M & $\mathrm{ns}$ & $\mathrm{ns}$ & $\mathrm{ns}$ & ns & $\mathrm{ns}$ \\
\hline Tome_D & ns & $\mathrm{ns}$ & ns & $*$ & ns & ns & M & ns & ns \\
\hline Voleri_D & ns & $\mathrm{ns}$ & $*$ & $* * *$ & $\mathrm{~ns}$ & $\mathrm{~ns}$ & $* * *$ & $*$ & $*$ \\
\hline Jelgava_L & ns & $* *$ & ns & $* * *$ & ns & ns & $* *$ & ns & ns \\
\hline Grīva_L & ns & ns & $*$ & $* * *$ & ns & ns & $*$ & $* * *$ & $\mathrm{~ns}$ \\
\hline
\end{tabular}

D - Daugava, L - Lielupe; ns, not significant; M, monomorphic loci; * $p<0.05$; ** $p<0.01$; *** $p<0.001$

Daugava River from Rīga (Voleri) (Voleri_D). A significant homozygote excess was observed in populations from the Daugava River in Rìga (Voleri_D) at five loci (Pfla L6, YP78; $p<0.001 ;$ YP111, YP60, and Pfla L2, $p$ 0.05), from the Lielupe River estuary at four loci (YP111, Pfla L6, $p<$ 0.001; Pfla L2, and YP78, $p<0.05$ ), and from Jelgava in Lielupe River at three loci (Pfla L10, YP78, $p<0,01$, and Pfla L6, $p<0.001$ ) (Table 3).

Maximal differences between the levels of observed and expected heterozygosity in the studied perch populations were found at loci Pfla L6 and YP78. Significant differences between observed and expected heterozygosity at locus Pfla L6 were found in populations from the Daugava River in the Rīga HPP (Tome_D) and in Rìga (Voleri_D) and from Lielupe River estuary (Grīva_L) and in Jelgava (Jelgava_L). At loci YP78, significant differences were found in populations from the Daugava River estuary in Riga (Voleri_D) and from the Lielupe River estuary (Grīva_L) and in Jelgava (Jelgava).

Three loci (Pfla L4, Pfla L2, and YP60) had little genetic differentiation $(0.023,0.009$, and 0.003 , respectively); four loci (Pfla L10, Svi L7, Svi L10 and YP111) had moderate differentiation $(0.063,0.096,0.137$, and 0.040, respectively). Two loci (Pfla L6 and YP78) had very high genetic differentiation ( 0.161 and 0.162 , respectively) between populations.

The presence of null alleles in the studied perch populations was not observed. The generalised data, which based on
Table 4. Pairwise $F_{S T}$ of genetic differentiation between perch populations from the Daugava and Lielupe Rivers

\begin{tabular}{lccc|c|c|c}
\hline Populations & Kegums_D & Tome_D & Voleri_D & Jelgava_L & Grīva_L \\
\hline Kegums_D & 0 & & & & \\
Tome_D & 0.075 & 0 & & & \\
Voleri_D & 0.119 & 0.078 & 0 & & \\
Jelgava_L & 0.161 & 0.104 & 0.066 & 0 & \\
Grīva_L & 0.109 & 0.072 & 0.052 & 0.057 & 0
\end{tabular}

nine microsatellite loci, show radically different genetic differentiation (Table 4). The lowest differentiation (pairwise $\mathrm{F}_{\mathrm{st}}$ ) was between populations from the Daugava River estuary in Rīga (Voleri_D) and the Lielupe River estuary (Grīva _L); and between populations from Jelgava (Jelgava_L) and the Lielupe River estuary (Grīva_L) pairs (0.052 and 0.057, respectively). The highest differentiation $(0.161)$ was between perch populations from the Kegums HPP (Kegums_D) and Jelgava (Jelgava_L). This is quite a high level of genetic differentiation, which correlates with geographic distance. Moderate genetic differentiation (0.05-0.15, Hartl, Clark 1997) was found between other populations.

Principal component analysis (PCA), a graph of genetic structuring among five perch populations in different locations from the Daugava and Lielupe rivers, clearly showed the genetic structuring of both the Daugava River samples (Voleri, Tome, and Kegums) and the Lielupe samples (Jelgava and Grīva) into different genetic groups (Fig. 3). PC1 


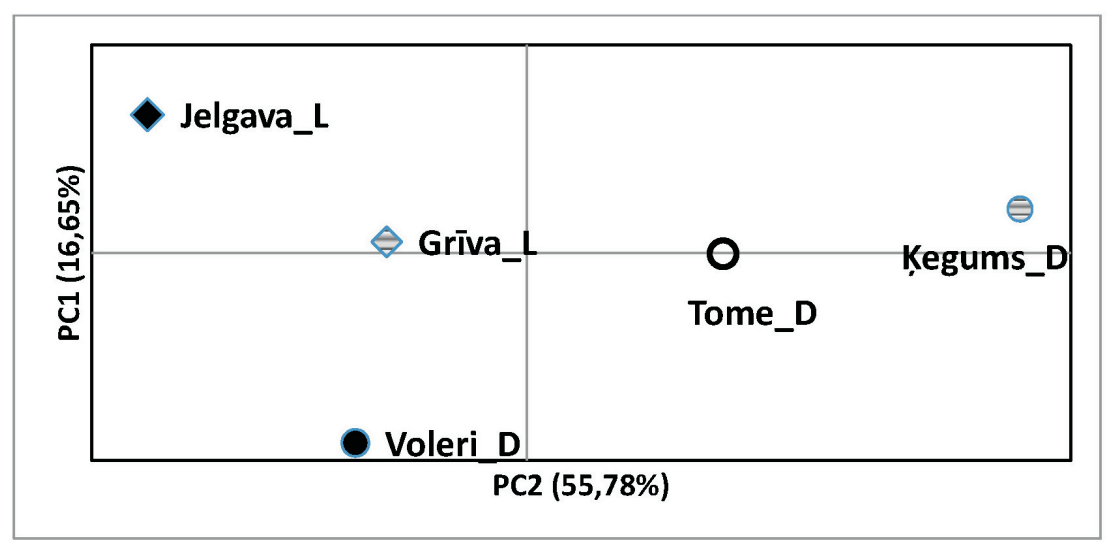

Fig. 3. Principal component analysis (PCA). Plot of genetic structuring among five perch populations.

and PC2 explained $16.65 \%$ and $55.78 \%$ of the total variation, respectively.

The Bayesian clustering analysis implemented in the STRUCTURE software identified two groups $(\mathrm{K}=2, \Delta \mathrm{K}=$ 4.62; $\ln \mathrm{P}(\mathrm{K}) \pm \mathrm{SD}=-3021.04 \pm 10.04)$, separating perch populations from from Lielupe River in Jelgava (Jelgava_L) from the other group (Fig. 2).

The Neighbor-Joining dendrogram (Fig. 4) based on Nei genetic distances (D) shows that the perch population from the Daugava River in Rìga HPP (Tome_D), and from Kegums HPP (Kegums_D) form separate groups (node robustness $89 \%$ ). The perch populations from Lielupe River in estuary (Grīva_L) and Jelgava city (Jelgava_L) form a separate group (node robustness $76 \%$ ), and the perch population from the Daugava River in Riga (Voleri_D) is clustered separately (node robustness is $74 \%$ ).

\section{DISCUSSION}

The anthropogenic influence of cities, navigable ports, and dams on rivers can affect the genetic structure of fish popu- lations. For the first time, we used the widely distributed freshwater fish European perch (Perca fluviatilis L.) as a model species to study the genetic structure of fish populations in different parts of the Latvian rivers under anthropogenic influence.

The greatest number of alleles and the maximum number of private alleles were found in the perch population from Daugava River in Riga (Voleri_D). For the other populations in Daugava River and Lielupe River, the average number of alleles per locus was low. This could be explained by the small sizes of the samples. However, the studied samples are quite numerous, and the sample size is sufficient for population genetic analysis. The Daugava River and its numerous tributaries forms a dendritic river network. An upstream decline in genetic diversity is generally expected in organisms inhabiting a dendritic river network because of the accumulation of allelic diversity below confluences of tributaries containing genetically differentiated populations (Morrissey and de Kerckhove, 2009; PazVinas and Blanchet, 2015). This may explain the increase in allelic diversity in the estuary, as a result of the mixing of different genotypes of perches that come here from their

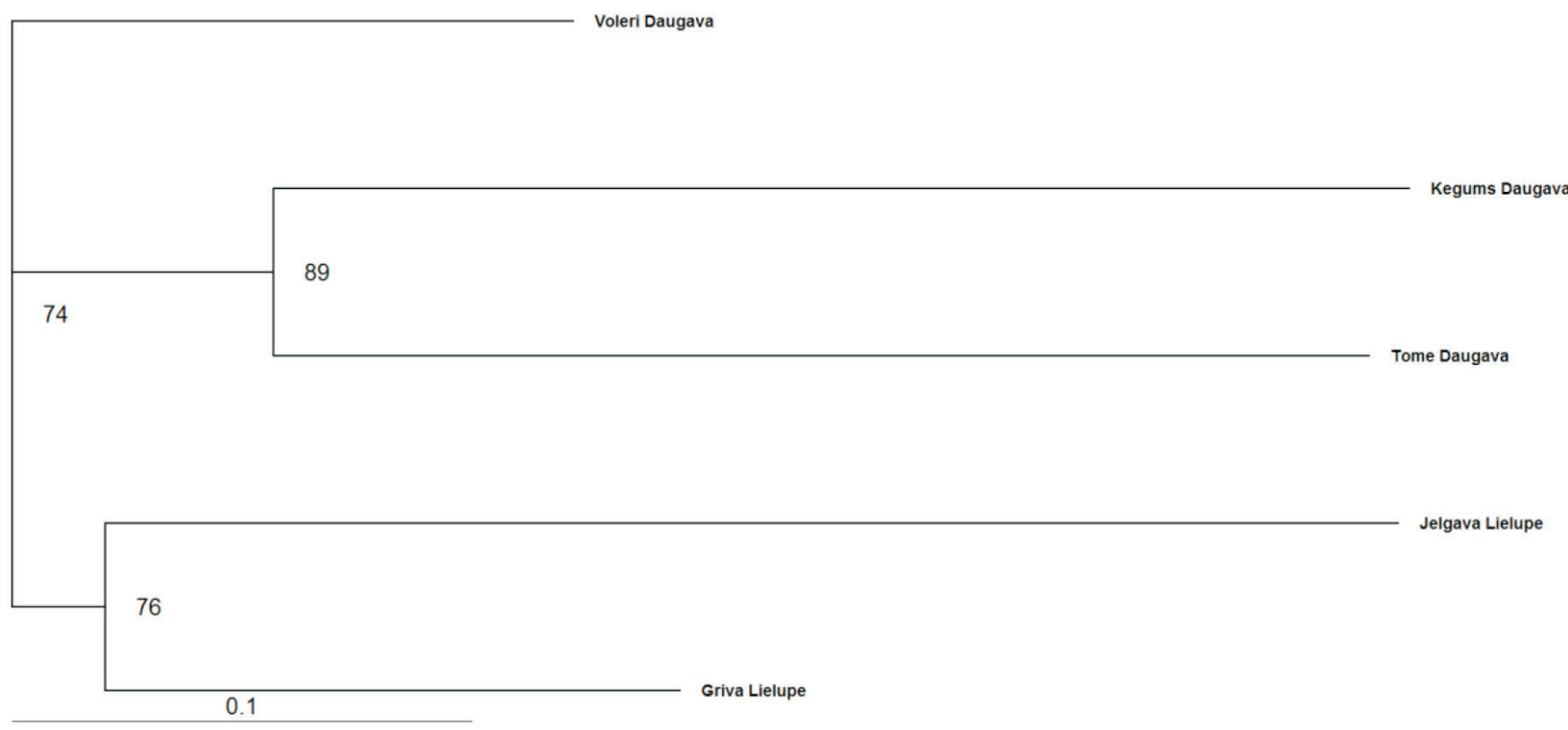

Fig. 4. The Neighbor-Joining dendrogram for the studied perch individuals (according to the genetic distances (D) (Nei et al., 1983). 
many tributaries. It is possible that the high number of private alleles is the consequences of mixing of various genomes, which could have been formed in the estuary of Daugava River in Rìga (Voleri_D and in estuary of Lielupe River as possible subsequent breeding, because the populations from different places are not geographically and reproductively isolated at this location. Private alleles can be indicators of gene flow and theoretical models of population structure indicated that the occurrence of private alleles was related to the mean number of migrants exchanged per generation between populations (Slatkin, 1985; Barton and Slatkin, 1986). However, it can be assumed that different genotypes of perch from tributaries cannot move freely and accumulate at the mouth of the Daugava River due to dams. We also observed an increase in allelic diversity at the mouth of the river on the Lielupe River, which has no dams.

Changes in water quality have been linked to changes in aquatic biota. Concentrations of nutrients, pesticides, organic chemicals, and heavy metal concentrations are often elevated in urban run-off and treated waste-water, which are major sources of effluents in many urban streams (Lieb and Carline, 2000; Shinya et al., 2000). Perhaps the increase in allelic diversity is influenced by various chemical compounds in the water within the territory of large cities, such as Rìga. Heterozygosity serves as an indicator of evolutionary potential and is important in determining population dynamics as well as population viability. A decrease in heterozygosity may lead to a decrease in adaptation in the population. An increase in the intra-population gene diversity associated with selective fishing was found by genetic monitoring of various fish species (Altukhov et al., 2000). Eurasian perch is a commercially intensively exploited freshwater fish species in Europe, and is a targeted angling species in many countries (Heermann et al., 2013). Selective fishing occurs in perch populations from Daugava River and also Lielupe River. The observed heterozygosity $\left(H_{o b s}\right)$ was quite high in all studied perch populations. The heterozygosity values were similar to those in other water reservoirs in Latvia, for example, in Kale Lake (Kokina et al., 2018) and in other Baltic countries (Pukk et al., 2016). Heterozygosity values in all studied perch populations of the Daugava River and Lielupe River are higher than in the Curonian Lagoon and the Gulf of Finland in the Baltic Sea (Sruoga et al., 2008; Pukk, et al., 2016). Perch populations from city regions have lower heterozygosity. These city perch populations are probably under selection pressure. The values of heterozygosity for three loci (Pfla L6, YP78, $Y P 111)$ indicated the potential robustness of these loci as genetic markers of population resistance, because they can reflect heterozygosity in populations. The highest genetic differentiation (0.161) based on $F_{s t}$ values was found between the perch populations from Daugava River (Kegums HPP reservoirs (Kegums_D)) and Lielupe River in Jelgava (Jelgava_L). Obviously, this reflects the geographic isolation of the Daugava and Lielupe River catchments and indicates the absence of gene flow between the studied perch populations. Genetic differentiation was significant for fish populations in the Daugava River between Kegums and
Rīga HPP reservoirs and between Rīga HPP reservoir and Daugava River in Rīga (Voleri_D). It was substantially higher than the differentiation between Lake Kale and Lake Babìtes in Latvia (Kokina et al., 2018).

This differentiation is apparently due to the fragmentation of populations caused by HPP dams. In a study of chub in the French river Durance, it was estimated that each dam adds a virtual distance of $34 \mathrm{~km}$ in terms of genetic differentiation (Dehais et al., 2010). The negative effects on populations of dams and HPP are likely to be pronounced for many other fish species having lower dispersal abilities (Wollebæk et al., 2011; Gouskov et al., 2016). The differentiation was quite low (0.052) between the perch populations in the Daugava River estuary of Riga and the Lielupe River estuary. This is due to the existence of the old riverbed of Lielupe River (Bullupe River) connecting the Daugava River estuary in Riga to the Lielupe estuary via which fish can migrate.

Bayesian clustering also revealed a similar result: the perch populations from the Daugava River and the Lielupe River estuary (Grīva_L) were clustered in one group. Only the perch population from Lielupe River in Jelgava (Jelgava_L) was separated from the other studied perch populations.

The Neighbor-Joining phylogenetic dendrogram indicated that the perch populations from Daugava River formed a separate group from the Lielupe River populations. The perch population from the Daugava River in Riga (Voleri_D) formed a separate group (node robustness is $74 \%$ ) from the other Daugava River perch populations. The main genetic differences between perch populations in Lithuania could be explained occurrence in different water basins (Butkauskas et al., 2012). It is possible that more pronounced genetic isolation of catchment areas of rivers exists, which could be detected by increasing the number of studied loci and regular genetic monitoring of the studied populations.

\section{ACKNOWLEDGEMENTS}

This study has been supported by the National Research Programme 2014-2017 "EVIDEnT" sub-project 4.6. "Freshwater ecosystem services and biological diversity".

\section{REFERENCES}

Abdul-Muneer, P. M. (2014). Application of microsatellite markers in conservation genetics and fisheries management: Recent advances in population structure analysis and conservation strategies. Genet. Res. Int., 2014, 691759.

Aljanabi, S. M., Martinez, I. (1997). Universal and rapid salt-extraction of high quality genomic DNA for PCR-based techniques. Nucleic Acids Res., 25 (22), 4692-4693.

Altukhov, Yu. P., Salmenkova, E. A., Omelchenko, V. T. (2000). Salmonid Fishes: Population Biology, Genetics and Management. John Wiley \& Sons. 368 pp.

Bahri-Sfar, L., Lemaire, C., Kalthoum, Ben Hassine, O., Bonhomme, F. (2000). Fragmentation of sea bass populations in the western and eastern 
Mediterranean as revealed by microsatellite polymorphism. Proc. R. Soc. B., 267 (1446), 929-935.

Barton, N. H., Slatkin, M. (1986). A quasi-equilibrium theory of the distribution of rare alleles in a subdivided population. Heredity, 56 (3), 409.

Behrmann-Godel, J., Gerlach, G. (2008). First evidence for postzygotic reproductive isolation between two populations of Eurasian perch (Perca fluviatilis L.) within Lake Constance. Front. Zool., 5 (1), 3.

Bourret, V., Couture, P., Campbell, P. G., Bernatchez, L. (2008). Evolutionary ecotoxicology of wild yellow perch (Perca flavescens) populations chronically exposed to a polymetallic gradient. Aquat. Toxicol., 86 (1), 76-90.

Butkauskas, D., Ragauskas, A., Sruoga, A., Kesminas, V., Ložys, L., Rashal, I., Tzeng, W.-N., Žalakevičius, M. (2012). Investigations into genetic diversity of the perch inhabiting Ignalina nuclear power plant cooler and other inland water bodies of Lithuania on the basis of mtDNA analysis. Veterinarija ir Zootechnika, 60 (82), 7-12.

Cornuet, J. M., Piry, S., Luikart, G., Estoup, A., Solignac, M. (1997). New methods employing multilocus genotypes to select or exclude populations as origins of individuals. Genetics, 153 (4), 1989-2000.

Dannewitz, J., Maes, G. E., Johansson, L., Wickström, H., Volckaert, F. A., Järvi, T. (2005). Panmixia in the European eel: A matter of time. Proc. $R$. Soc. B, 272 (1568), 1129-1137.

Dehais, C., Eudeline, R., Berrebi, P., Argillier, C. (2010). Microgeographic genetic isolation in chub (Cyprinidae: Squalius cephalus) population of the Durance River: Estimating fragmentation by dams. Ecol. Freshw. Fish., 19 (2), 267-278.

Dynesius, M., Nilsson, C. (1994). Fragmentation and flow regulation of river systems in the northern third of the world. Science, 266 (5186), 753-762.

Earl, D. A. (2012). STRUCTURE HARVESTER: A website and program for visualizing STRUCTURE output and implementing the Evanno method. Conserv. Genet. Resour., 4 (2), 359-361.

Ellstrand, N. C., Elam, D. R. (1993). Population genetic consequences of small population size: Implications for plant conservation. Annu. Rev. Ecol. Syst., 24 (1), 217-242.

Fokina, O., Grauda, D., Rashal, I. (2015). Genetic diversity of two perch Perca fluviatilis populations of the Latgale region. In: Environment. Technology. Resources. Proceedings of the 10th International Scientific and Practical Conference, 18-20 June, 2015, Rēzekne, Latvia, Volume II, pp. 96-98.

Gouskov, A., Reyes, M., Wirthner-Bitterlin, L., Vorburger, C. (2016). Fish population genetic structure shaped by hydroelectric power plants in the upper Rhine catchment. Evol. Appl., 9 (2), 394-408.

Gouskov, A., Vorburger, C. (2016). Postglacial recolonizations, watershed crossings and human translocations shape the distribution of chub lineages around the Swiss Alps. BMC Evol. Biol., 16, 185-198.

Gum, B., Gross, R., Kuehn, R. (2005). Mitochondrial and nuclear DNA phylogeography of European grayling (Thymallus thymallus): Evidence for secondary contact zones in central Europe. Mol. Ecol., 14 (6), $1707-1725$.

Heermann, L., Emmrich, M., Heynen, M., Dorow M., König U., Borcherding, J., Arlinghaus R. (2013). Explaining recreationalangling catch rates of Eurasian perch Perca fluviatilis: the role of natural andfishing-related environmental factors. Fish. Manage. Ecol., 20, 187-200.

Hubisz, M. J., Falush, D., Stephens, M., Pritchard, J. K. (2009). Inferring weak population structure with the assistance of sample group information. Mol. Ecol. Res., 9 (5), 1322-1332.

Khedkar, G. D., Jamdade, R., Naik, S., David, L., Haymer, D. (2014). DNA barcodes for the fishes of the Narmada, one of India's longest rivers. PLoS One, 9 (7), e101460.
Kokina, I., Rubenina, I., Bankovska, L., Mickeviča, I., Gavarāne, I. (2018). Case study of microsatellite polymorphism of European perch in selected commercially important lakes of Latvia. Biologia, 73 (3), 273-280.

Langella, O. (2005). Populations, a free population genetic software (1990-2005). http://bioinformatics.org/ tryphon/ populations/ (accessed 17 February 2019).

Leclerc, D., Wirth, T., Bernatchez, L. (2000). Isolation and characterization of microsatellite loci in the yellow perch (Perca flavescens), and crossspecies amplification within the family Percidae. Mol. Ecol., 9 (7), 995-997.

Li, L., Wang, H. P., Givens, C., Czesny, S., Brown, B. (2007). Isolation and characterization of microsatellites in yellow perch (Percaflavescens). Mol. Ecol. Notes, 7 (4), 600-603.

Lieb, D. A., Carline, R. F. (2000). Effects of urban runoff from a detention pond on water quality, temperature and caged Gammarus minus (Say) (Amphipoda) in a headwater stream. Hydrobiologia, 441 (1), 107-116.

Lynch, M., Conery, J., Burger, R. (1995). Mutation accumulation and the extinction of small populations. Amer. Nat., 146 (4), 489-518.

Morrissey, M. B., de Kerckhove, D. T. (2009). The maintenance of genetic variation due to asymmetric gene flow in dendritic metapopulations. Amer. Nat., 174 6), 875-889.

Nagylaki, T. (1998). Fixation indices in subdivided populations. Genetics, 148 (3), 1325-1332.

Nei, M. (1973). Analysis of gene diversity in subdivided populations. Proc. Nat. Acad. Sci. USA, 70 (12), 3321-3323.

Nei, M. (1978). Estimation of average heterozygosity and genetic distance from a small number of individuals. Genetics, 89 (3), 583-590.

Nei, M. (1987). Molecular Evolutionary Genetics. Columbia University Press, New York. 512 pp.

Nei, M., F. Tajima, Tateno, Y. (1983). Accuracy of estimated phylogenetic trees from molecular data. 2. Genefrequency data. J. Mol. Evol., 19, $153-170$.

Nei, M., Takezaki, N. (1994). Estimation of genetic distances and phylogenetic trees from DNA analysis. In: Proceedings of the $5^{\text {th }}$ World Congress on Genetics Applied to Livestock Production. Gene Mapping; Polymorphisms; Disease Genetic Markers; Marker Assisted Selection; Gene Expression; Transgenes; Non-convention, 7-12 August 1994. Ontario, Canada, Vol. 21 pp. 405-412.

Nelson J. S. (2006). Fishes of the World. Fourth edition. John Wiley Sons, Hoboken. 624 pp

Nfon, E., Cousins, I. T., Järvinen, O., Mukherjee, A. B., Verta, M., Broman, D. (2009). Trophodynamics of mercury and other trace elements in a pelagic food chain from the Baltic Sea. Sci. Total Environ., 407 (24), 6267-6274.

O'Reilly 3rd, C. A., Tushman, M. L. (2004). The ambidextrous organization. Harvard Bus Rev., 82 (4), 74.

Page, R. D. M. (1996). TreeView: An application to display phylogenetic trees on personal computers. Comput. Appl. Biosc., 12, 357-358.

Paz-Vinas, I., Blanchet, S. (2015). Dendritic connectivity shapes spatial patterns of genetic diversity: A simulation-based study. J. Evol. Biol., 28 (4), 986-994.

Peakall, R. O. D., Smouse, P. E. (2006). GENALEX 6: Genetic analysis in Excel. Population genetic software for teaching and research. Mol. Ecol. Notes, 6 (1), 288-295.

Pukk, L., Kuparinen, A., Leili, J., Gross, R., Vasemägi, A. (2013). Genetic and life-history changes associated with fisheries-induced population collapse. Evol. Appl., 6 (5), 749-760.

Pukk, L., Gross, R., Vetemaa, M., Vasemägi, A. (2016). Genetic discrimination of brackish and freshwater populations of Eurasian perch (Perca fluviatilis L.) in the Baltic Sea drainage: Implications for fish forensics. Fisher. Res., 183, 155-164. 
Ragauskas, A., Butkauskas, D. Sruoga, A. (2014). Investigation into genetic diversity of perch inhabiting Lake Drūkšiai and other water bodies of Lithuania on the basis of mtDNA analysis. Zool. Ecol., 24 (2), 154-159.

Richard, G.-F., Kerrest, A., Dujon, B. (2008). Comparative genomics and molecular dynamics of DNA repeats in eukaryotes. Microbiol. Mol. Biol., 72 (4), 686-727.

Seeb, J. E., Carvalho, G., Hauser, L., Naish, K., Roberts, S. Seeb, L. W. (2011). Single-nucleotide polymorphism (SNP) discovery and applications of SNP genotyping in nonmodel organisms. Mol. Ecol. Res., 11, 1-8.

Shinya, M., Tsuchinaga, T., Kitano, M., Yamada, Y., Ishikawa, M. (2000). Characterization of heavy metals and polycyclic aromatic hydrocarbons in urban highway runoff. Water Sci. Technol., 42 (7-8), 201-208.

Slatkin, M. (1985). Rare alleles as indicators of gene flow. Evolution, 39 (1), 53-65.

Sruoga, A., Butkauskas, D., Rashal, I. (2008). Evaluation of genetic diversity of perch (Perca fluviatilis) and pikeperch (Sander lucioperca) populations from Curonian lagoon and inshore waters of the Baltic Sea. Acta Biol. Univ. Daugavp., 8 (1), 81-88.
Svanbäck, R., Eklöv, P. (2006). Genetic variation and phenotypic plasticity: Causes of morphological variation in Eurasian perch. Evol. Ecol. Res., 8 (1), 37-49.

Škute, N. Oreha, J. (2016). Evaluation of some microsatellite markers variability in the study of genetic structure of vendace (Coregonus albula (L.) populations from Latvian lakes. Contemp. Probl. Ecol., 9 (2), 157-165.

Van Oosterhout, C., Hutchinson, W. F., Wills, D. P., Shipley, P. (2004). MICRO-CHECKER: software for identifying and correcting genotyping errors in microsatellite data. Mol. Ecol. Notes, 4 (3), 535-538.

Wollebæk, J., Heggenes, J. Røed, K. H. (2011). Population connectivity: Dam migration mitigations and contemporary site fidelity in arctic char. BMC Evol. Biol., 11, 207.

Ward, J. V., Stanford, J. A. (1983). The serial discontinuity concept of lotic ecosystems. In: Fontaine, T. D., Bartell, S. M. (eds.). Dynamics of Lotic Ecosystems. Ann Arbor Science, pp. 29-42.

Wirth, T., Saint-Laurent, R., Bernatchez, L. (1999). Isolation and characterization of microsatellite loci in the walleye (Stizostedion vitreum), and cross-species amplification within the family Percidae. Mol. Ecol., 8 (11), 1960-1962.

Yeh, F. C., Yang, R. C., Boyle, T. (1999). POPGENE 32-version 1.31. Population Genetics Software.

Received 12 January 2020

Accepted in the final form 16 February 2021

\section{ASARU PERCA FLUVIATILIS (L.) POPULĀCIJU GENĒTISKĀ STRUKTŪRA HES FRAGMENTĒTĀS (DAUGAVA) UN NEFRAGMENTĒTĀS (LIELUPE) LATVIJAS UPĒS}

Ūdens ekosistēmām ir būtiska loma bioloǵiskās daudzveidības un vides kvalitātes saglabāšanā Latvijā. Zivju resursi ir vieni no vērtīgākajiem bioloğiskajiem resursiem Latvijā. Lai novērtētu ekonomiskās aktivitātes (pilsētas, hidroelektrostacijas u.c) antropogēno ietekmi uz saldūdens ekosistēmu, tika pētīta Daugavas un Lielupes upes asaru Perca fluviatilis (L.) populāciju ǵenētiskā struktūra, izmantojot devinus DNS mikrosatellītu lokusus (Pfla L4, Pfla L10, Pfla L2, Pfla L6, YP111, YP78, YP60, Svi L10, Svi L7). Tika analizēta ǵenētiskā daudzveidība, polimorfisma līmenis, alēlu daudzveidība, novērotā un paredzamā heterozigotāte, populācijas strukturēšana; izmantota Beiesa pieeja. Tika parādīts, ka asaru populācija Daugavā Rīgas pilsētas teritorijā būtiski atškiras starp visām pārējām populācijām, un šajā populācijā ir heterozigotu deficīts. Asaru populācijas ğenētiskā diferenciācija Daugavā ìr būtiska starp Keguma un Rīgas HES ūdenskrātuvēm, populācijas fragmentācijas rezultātā. 